\title{
Vida e obra Roland Barthes e a escrita do Diário
}

\author{
Alberto Giordano ${ }^{1}$ \\ Universidad Nacional de Rosario- Argentina
}

Quantas vezes ouvimos dizer que o discurso da crítica literária é um dos mais permeáveis ao influxo das modas intelectuais, e que a obra de Roland Barthes, tomada em seu desenvolvimento, ou seja, na sucessão de livros que a compõem, de modo quase espetacular se oferece como exemplo desta sujeição? Haveria nela um primeiro momento, brechtiano, no qual a especificidade literária se define em termos ideológicos, como compromisso formal determinado em última instância pela História. A esse momento sociológico, marcado pelo encontro de marxismo e existencialismo, seguiria outro com menos pretensões políticas, em que os termos que explicam o funcionamento discursivo da literatura são provenientes da linguística e da semiologia. O breve interregno estruturalista daria lugar, em seguida, à teoria do texto, escorada massivamente pela psicanálise lacaniana e pelas filosofias da diferença (Deleuze e Derrida), na qual já não se trata do específico, mas do singular, da literatura como acontecimento irredutível. Do textualismo generalizado se desprenderia o último momento, o do giro autobiográfico em clave nietzscheana: a literatura devém o Outro, o interlocutor eminente e desconhecido dos exercícios éticos que o crítico executa quando ensaia a microfísica de sua estupidez. Tudo isto é uma coleção de generalidades desprovida de matizes, de inflexões sutis, mas também a reconstrução em grandes traços de como efetivamente se encadearam, sempre em sintonia com a atmosfera dos tempos, os contextos intelectuais em que Barthes a cada vez encontrou as "abstrações" que lhe permitiram canalizar, em termos conceituais, os "gestos" que seu corpo de crítico literário fazia em dado momento. ${ }^{2}$

Sem desconhecer as virtudes pedagógicas deste tipo de apresentações, nas quais há um sujeito que se conserva idêntico a si mesmo através de todos os momentos, ainda que não seja mais que como sujeito à moda de cada temporada, prefiro pensar a obra de Barthes, sobretudo, em termos de recomeço e
1. GIORDANO, Alberto. "Vida y obra. Roland Barthes y la escritura del Diario". In: - La contraseña de los

solitarios. Diarios de escritores. Rosario: Beatriz Viterbo Editora, 2011, p. 91-108. Tradução de Carlos Eduardo Schmidt Capela. Alberto Giordano, crítico e ensaísta, é professor da Universidad Nacional de Rosario (UNR), na Argentina. Todas as passagens citadas pelo autor, ao longo do ensaio, foram aqui traduzidas diretamente da versão espanhola. As traduções de Barthes ao português encontram-se, ao lado das suas versões castelhanas, nas Referências bibliográficas (N. T.).

2. Cf. BARTHES, Roland. "Los gestos de la idea". In: Roland Barthes por Roland Barthes, 1978, p. 108. 
3. Cf. GIORDANO, Alberto. Roland Barthes. Literatura y poder, 1995.

4. Das várias superstições morais que distanciam o crítico da afirmação da literatura como ocorrência intransitiva, a crença no valor pedagógico do que sucede na leitura é talvez a mais resistente. $\mathrm{O}$ recurso ao estereótipo "o que a literatura nos ensina" (quem não cedeu a seus encantos?), embora se refira a algo que os saberes que a rodeiam desconhecem, impõese, em maior ou menor medida, como um limite infranqueável contra o qual se debilita qualquer tentativa de pensar criticamente uma ética do acontecimento literário.

5. BARTHES, Roland. El placer del texto seguido por Lección inaugural, 1982, p. 131. inatualidade, isto é, de insistência e afirmação do anacrônico e do indeterminado (fechada e ao mesmo tempo subtraída a qualquer presente). A evidência do desenvolvimento e da sujeição à lei do contexto dissimula o movimento espiralado e descontínuo, feito de progressões e deslocamentos imprevistos, de permanências obsessivas e discretas transformações, que caracteriza a errância de qualquer busca essencial. Como tudo o que impõe seu interesse, porque nos atrai para a experiência de sua ambiguidade, os ensaios de Barthes exibem as marcas do horizonte cultural que os condicionou, isso na mesma medida em que assinalam o advento de possibilidades críticas que recém começamos a imaginar. Estas permanecem entreditas, como uma promessa de sentido que desconecta cada livro do contexto que o identifica para que possamos reescrevê-lo.

Certa vez fiz girar a constelação de ensaios nos quais Barthes dialoga com a literatura ao redor de um centro instável, a interrogação acerca do poder e das potências, mesclando os distintos momentos de sua obra a ponto de impugnar as condições que serviram para delimitá-los. ${ }^{3} \mathrm{O}$ que pode a literatura e como pode a crítica responder ativamente a sua afirmação intransitiva? Cada vez que a subjetividade do ensaísta aparece tensionada pela coexistência de dois impulsos heterogêneos, os que respondem ao intransferível dos afetos que despertam certas leituras ("isto foi escrito para mim!"), e os que obedecem à necessidade profissional de atribuir a esta ocorrência, que se quer misteriosa, um valor definido ("isto faz bem, porque nos ensina algo") ${ }^{4}$; cada vez que os modos do ensaio barthesiano afirmam, simultaneamente, "o Irredutível da literatura: o que nela resiste e sobrevive aos discursos tipificados que a rodeiam" ${ }^{5}$, e os compromissos morais que o desejo de saber contrai com a cultura, assistimos ao recomeço da crítica como busca da literatura, busca determinada pela indeterminação do literário, que não nega, mas sim neutraliza, e deixa inoperante, depois de reclamá-lo, o exercício da contextualização.

Desta vez gostaria de tentar uma excursão muito menos ambiciosa, atendo-me à insistência de outras perguntas, aquelas que atravessam a deliberação que Barthes teria sustentado, durante quase quatro décadas, quanto à conveniência de manter um diário de escritor. Por diário de escritor entendo, quando salto da evidência empírica à arrogância conceitual, um diário que, sem renunciar ao registro do privado ou do íntimo, expõe o encontro entre notação e vida desde uma perspectiva literária, e, desde essa perspectiva, interroga-se sobre o valor e a eficácia do hábito (disciplina, paixão, mania?) de anotar algo a cada jornada.

Ainda que de modo geral a situem na borda exterior das margens que delimitam sua atividade, a prática do diário coloca aos escritores problemas específicos de técnica literária, relacionados à consciência adquirida com respeito aos poderes e aos 
limites da linguagem quando a proposta é representar ou capturar, de algum modo, fragmentos de vida; assim como também lhes coloca questões mais mundanas, ligadas às possibilidades ou aos riscos da autofiguração (através de que imagem ele será reconhecido, a de um egotista impenitente, a de um memorialista ou a de um experimentador - segundo a desgastada metáfora do diário como laboratório?). Quando falo de perspectiva literária, penso, ao mesmo tempo, em exigências institucionais determinadas historicamente e nos requerimentos do desejo de literatura (desejo de um encontro imediato entre vida e escrita) que secretamente liga o escritor a sua obra.

Tanto o primeiro quanto o último ensaio que Barthes publicou em vida tratam da escrita do Diário. É só uma casualidade, mas como não usufruir dela para dar ao começo da argumentação um lance de efeito? Em "Notas sobre André Gide e seu Diário", de 1942, o jovem Barthes não duvida em afirmar a continuidade entre escrita íntima e obra de arte, quando as confissões se autonomizam com respeito ao exercício espiritual que as desperta "graças ao prazer produzido por lê-las" ". Ainda mais interessante, e mais radical como gesto de leitura imaginativa, é a figuração do diarista como personagem literário. Os papéis pessoais de um escritor oferecem chaves para o deciframento psicológico e para a interpretação estética. Barthes não se priva destas convenções, mas, além disso, descobre no diário potências imaginárias que revestem o autobiográfico com a ordem ambígua da ficção. Pelo estilo de suas notações, mas, sobretudo, pela força ao mesmo tempo disciplinada e insensata que o leva a recomeçar quase infinitamente o exercício, o Gide do Diário é talvez a invenção mais fascinante de sua literatura: um ser fugidio, feito de contradições e simultaneidades anômalas, flutuante pela firmeza de suas convicções, um sábio que, no entanto, não é razoável, porque se sustenta no tremor mais que na certe$\mathrm{za}^{7}$ No outro extremo da diacronia, 1979, encontramos uma "Deliberação" pessoal sobre o gênero, que ao menos retoricamente tinha que ajudá-lo, nesse momento, a tomar uma decisão: "deveria escrever um diário com vistas a sua publicação? Poderia converter o diário em uma 'obra"'?8 (Barthes, 1986: 366). Este ensaio, no qual a especulação crítica coexiste com a transcrição de alguns exercícios práticos (oito entradas de um diário de 1977, e mais uma de 1979), logo merecerá um comentário que diz respeito a seus alcances éticos (não tão profundos como parecem à primeira vista) e ao interesse de alguns motivos teóricos examinados. No momento, recordo que Barthes não resolve o problema, que não resolvê-lo é, em seu caso, o resultado de tê-lo colocado com rigor e coerência, e antecipo que as razões que justificam esse final decepcionante põem nas mãos do leitor ferramentas para prolongar, e talvez resolver, a deliberação em outras direções.
6. Idem. Variaciones sobre literatura, 2003, p. 13.

7. Quando, em uma das sessões do curso "A preparação do romance", a de 19 de janeiro de 1980, retorna ao que então chamará de "modernidade" do Diário gidiano, Barthes irá expor a transformação do diarista-testemunha em "autor de escrita" (o que chamo de personagem literário) a partir da complexidade de níveis que supõe a enunciação do Eu confessional: "1) Eu é sincero.

2) Eu é de uma sinceridade artificial. 3) A sinceridade não é pertinente, converte-se em uma qualidade do texto que deve ser colocada entre aspas". Idem.

La preparación de la novela. Notas de cursos y seminarios en el Collège de France, 2005, 277. Adiante voltarei a tratar da necessidade de colocar entre aspas o valor "sinceridade" na prática dos intimistas modernos, entre os quais encontramos o próprio Barthes.

8. Idem. Lo obvio y lo obtuso. Imágenes, gestos, voces, 1986, p. 366. 
9. Idem. Roland Barthes por Roland Barthes, 1978, p. 104.
O mais surpreendente do primeiro ensaio é que Barthes já havia descoberto, ao escrevê-lo, o procedimento e o princípio construtivo que melhor responderiam, em quase qualquer contexto, a sua sensibilidade crítica: o fragmento e a escrita rapsódica. E, ainda, como podia argumentar em prol do valor de tais preferências em termos de rigor metodológico: valeria mais a pena correr os riscos da incoerência do que sistematizar um processo aberto às contradições. Quando o exercício do descontínuo acaba por tornar-se um hábito legitimado, celebrado sem necessidade de justificações, exaltará o isomorfismo entre o tema daquele texto precoce, a escrita do diário, e o modo que elegeu para expô-lo, a escrita do ensaio, com o que confere a seu devir crítico, retrospectivamente, a aparência algo irônica de um destino secreto em vésperas de consumação.

Com o álibi da dissertação destruída se chega à prática regular do fragmento. Em seguida, do fragmento se passa ao ‘diário'. Não é, então, a meta de tudo isso a de outorgar-se o direito de escrever um 'diário'? Não tenho razão em considerar tudo o que escrevi como um esforço clandestino e obstinado para fazer que reapareça um dia, livremente, o tema do 'diário' gidiano? Talvez seja simplesmente o texto inicial que aflora no horizonte último [...].

No entanto, o 'diário' (autobiográfico) está hoje desacreditado. ${ }^{9}$

Entramos com plenitude no clima espiritual da "Deliberação", um espaçamento que tem lugar quando a dúvida e a inquietação interferem na realização de um desejo arcaico que de todo modo se obstina. A trajetória vertiginosa que toma o pensamento crítico do último Barthes estenderia as ambiguidades de sua transferência com relação a Gide. Os ímpetos de fazer literatura haviam sido despertados pela leitura do Diário, para parcialmente se satisfazer, contudo, não através da escrita de um romance que abraçasse o mundo com generosidade (isso será até o final o impossível por definição e o summum do desejável), mas através de outra forma fragmentária e de estatuto incerto, a do ensaio. A partir deste deslocamento original, que não deixará de ocorrer ao longo de toda a sua obra, impregnando-a de beleza e intensidade, há que se ler a vontade programática, tão manifesta nos últimos anos, de que o ensaio se metamorfoseasse em diário para mostrar, para além das exigências e das aventuras conceituais, a vida como acontecimento sutil. O problema é que os prazeres e as convicções do leitor que pode descobrir literatura em uma notação desprovida de intenções estéticas não se projetam sobre sua metamorfose em escritor-diarista. Os fantasmas do descrédito cultural (até Proust debochou dos que praticavam o gênero) ofuscavam a peripécia.

Um dos dois cumes que a experimentação barthesiana alcançou com o romanesco da escrita ensaística, esse limite da 
argumentação na qual a potência indizível dos afetos intensifica e ao mesmo tempo neutraliza a precisão conceitual, é a conferência "Durante muito tempo, fui dormir cedo" ", apresentada no Collège de France, em 19 de outubro de 1978. ${ }^{11}$ Menos por um impulso vitalista que por uma necessidade extrema de sobrevivência, Barthes afirma a vontade de inscrever seu trabalho, a partir desse momento, sob a divisa incipit Vita Nova. Este programa, ao qual já havia aludido na Aula inangural da cátedra de Semiologia Literária, tem alcance existencial e se baseia em uma teoria das "idades" tomadas como mutação, e não como progressão das possibilidades de vida. A exigência de trabalhar ativamente sobre si mesmo para proporcionar o advento do novo não nasce de uma reivindicação moral de aperfeiçoamento, mas da necessidade de se recuperar da aflição e da acedia. A relação cada vez mais íntima com os fantasmas da impotência amorosa e criativa deveria ser, no momento em que a vida recomeçasse, condição quase negativa para sua renovação.

Como havia feito Proust, com quem estabelece uma identificação quase absoluta, mediada pela crença no valor absoluto da literatura, Barthes encomenda sua mutação ao descobrimento "de uma forma que recolha o sofrimento (que acabara de conhecer de maneira absoluta, com a morte de sua mãe) e o transcenda"12. Uma forma que não seria, em seu caso, a do ensaio (porque sente, talvez com razão, que já esgotou suas possibilidades romanescas do gênero), nem a do romance em seu sentido convencional (porque sabe, com certeza, que não poderia escrever um ${ }^{13}$ ). À "terceira forma", que serviria para representar a ordem dos afetos com discrição, sem impor a ela a fixidez dos lugares comuns sentimentais, nem a impostura do egotismo, Barthes denomina, de qualquer maneira, Romance, porque entende que só o Romance poderia mobilizar as potências correspondentes a sua idade: a força impessoal do amor e o poder da compaixão. Não é que esteja pensando em um relato, nem sequer em sua versão fragmentada, mas sim em uma conjunção aleatória de anotações capazes de conjugar a elegância formal com a verdade do instante em que se insinua um afeto. A prática da anotação registra contingências e individualiza matižes, "capta uma rebarba do presente, tal como salta à nossa observação" ${ }^{14}$, ou seja, tal como nos perfura sutilmente, enceguecendo a compreensão (essa cegueira pontual recebe, entre outros, os nomes de gozo, punctum e sentido obtuso).

Barthes tinha presente a possibilidade de um texto que ligasse "pedaços de romance" 15 , sem forçar a continuidade, pelo menos desde meados dos anos 60. Nos exercícios de um aprendiz anônimo, que finalmente não se converteu em escritor (a alegoria autobiográfica parece evidente), encontrou fragmentos com impulsos romanescos, mas livres de qualquer desenvolvimento, nos quais a brevidade supunha um ritmo de interrupções
10. "Durante muito tempo, fui dormir cedo", foi publicado, em tradução de Mario Laranjeira, em BARTHES, Roland. O rumor da língua. São Paulo: Brasiliense, 1988, p. 283-294. (N. T.)

11. O outro cume é $A$ câmara clara, publicada em 1980, mas escrita entre 15 de abril e 3 de junho de 1979. Os dois cursos que compõem A preparação do romance ("Da vida à obra", ministrado entre 2 de dezembro de 1978 e 10 de março de 1979, e "A obra como vontade", entre 1 de dezembro de 1979 e 25 de fevereiro de 1980) desenvolvem, com luminosa pedagogia, os fundamentos éticos e o sentido das decisões retóricas tomadas para a escrita dos dois ensaioslimite.

\section{BARTHES, Roland. El} susurro del lenguaje. Más allá de la palabra y la escritura, 1987a, p. 329.

13. Notas para um ensaio sobre continuidade e variações na grande tradição francesa dos escritores-moralistas: a primeira razão que Barthes fornece para justificar a impossibilidade de escrever um romance, não saber mentir (ainda que queira, ainda que tampouco possa dizer a Verdade), é quase a mesma que se dava Charles du Bos, no Diário, quando se lamentava de sua escrupulosa e muito literal concepção da sinceridade: “ainda que possuísse essa imaginação criativa que não tenho, não estou absolutamente seguro de que pudesse consentir em servir-me dela, de que pudesse chegar a impor silêncio a esse aspecto profundo e como que intratável de minha natureza, que se rebela contra toda transposição, qualquer que seja". DU BOS, Charles, Extractos de un Diario. 1908-1928, 1947, p. 246. Com a psicanálise de seu lado, Barthes acrescenta 
ao argumento moral uma torção reveladora: "a recusa de 'mentir' pode remeter a um Narcisimo: não tenho, me parece, mais que uma imaginação fantasmática (não fabuladora), isto é, narcisista". BARTHES, Roland. La preparación de la novela. Notas de cursos y seminarios en el Collège de France, 2005, p. 265.

\section{Idem. La preparación de la} novela. Notas de cursos y seminarios en el Collège de France, 2005, p. 141.

15. Idem. El susurro del lenguaje. Más allá de la palabra y la escritura, 1987a, p. 272.

16. Ibidem, p. 273.

17. Estando por demais acomodado às facilidades do turismo sexual no norte africano, a impenetrabilidade dos chinesinhos decepcionou-o até chegar ao ponto da estupidez: "[E com tudo isso não cheguei a ver a pica de um único chinês. E o que se conhece de um povo, se não se conhece seu sexo?]". Idem. Diario de mi viaje a China, 2010, p. 114. À luz desta ocorrência, temo que Barthes superestimava seus conhecimentos do povo japonês e marroquino, do mesmo que a eficácia gnoseológica da prostituição adolescente. e recomeços deslocados, e não um redobramento a partir da clausura sintática. Chamou-os incidentes, "coisas que caem, sem contundência e, no entanto, com um movimento que não é infinito: continuidade descontínua dos flocos de neve"16. Sob este título, entre seus papeis póstumos, os editores encontraram um texto pronto para ser publicado na Tel Quel, no qual Barthes recolheu uma série heterogênea de anotações casuais tomadas no Marrocos, em 1968 e 1969. São instantâneos na borda da insignificância, desprovidos de valor representativo (não apontam para a reconstrução do caráter do observador, nem para a idiossincrasia dos seres observados), rastros evanescentes de alguns encontros fortuitos com gestos ou imagens impregnados de sensação de vida e certeza de realidade.

Quando, uns anos depois daquele périplo encantador por Tânger e Rabat, Barthes assume, desenganado, o compromisso de um serviço militante obrigatório, a viagem à China da Revolução Cultural em companhia dos amigos da Tel Quel, manterá, entre 11 de abril e 4 de março de 1974, um diário de viagem no qual irá registrar com obsessão cada visita tediosa de cada jornada extenuante (a fábricas, escolas, exposições industriais, estaleiros, hospitais, museus, parques e espetáculos esportivos), com vistas à escrita de um testemunho ideológico pessoal que publicará em seu regresso. (Como estes diários foram concebidos meramente como ajuda-memória para facilitar a redação do testemunho, ainda que também cumpram a função de refúgio e de resguardo do equilíbrio sentimental do viajante, e registrem aqui e ali o despontar do curioso, eles não participam em absoluto da busca existencial-literária da "terceira forma", e estão muito longe de responder às exigências da Vita Nova).

A decepção e o fastio que provoca, inclusive em um barthesiano impenitente, a leitura do Diário de minha viagem à China, correspondem à decepção e ao fastio experimentados por Barthes ao longo de toda a missão, que ele não fez muito mais do que registrar. A China resultou-lhe insossa e submersa pela reprodução de estereótipos políticos. Os hóspedes, embora hospitaleiros, atuavam como máquinas falantes, insípidas, sem dobras verbais, a serviço das arrogâncias estalinistas. A programação sem pausa nem fissuras a que o périplo esteve submetido esterilizou a possibilidade de surpresas e incidentes, sobretudo os eróticos, que o viajante perseguia em vão, com obstinação adolescente (não eram passados dois dias da chegada a Pequim e já estava se lamentando pelo inalcançável de umas mãos formosas, pela impossibilidade de conhecer o rapaz do pescocinho branco e limpo ${ }^{17}$ ).

A prática do diário compartilha, com os cadernos de incidentes, o registro sem ataduras retóricas do matiz e da contingência intransitiva (a ocorrência discreta daquilo que não terá projeções), mas acrescenta, ademais, a possibilidade de figurar 
um eu pulverizado e incerto, sobre cuja descontinuidade poderia ser sustentada a metamorfose artística da própria vida. Este é o único ponto de suas especulações sobre a preparação do romance no qual Barthes se afasta de Blanchot (celebro o desprendimento, porque às vezes me entristece a certeza, em que sigo apostando em sala de aula, de que o autor de $O$ espaço literário sempre tem a última palavra sobre qualquer problema de ordem literária).

Admiro-o, mas me parece que [Blanchot] fixa demasiadamente as coisas na oposição pessoal/impessoal - há uma dialética própria da literatura (e creio que tem futuro) que faz com que o sujeito possa oferecer-se como criação da arte; a arte pode atuar na fabricação mesma do indivíduo; o homem se opõe menos à obra se faz de si mesmo uma obra. ${ }^{18}$

Será preciso relembrar que o futuro deste dandismo foi ainda mais promissor do que Barthes suspeitava?

Segundo uma tradição francesa tão enraizada e disseminada como a dos cultores do intimismo, e é possível considerá-la como a contraparte reativa, o diário seria a forma mais imediata com a qual um escritor pode fazer de sua vida uma obra, e, em consequência, a mais aberta aos riscos do egotismo, da preguiça e da inautenticidade. Não raro, na prática de um único escritor, coexistem humores identificados com cada uma destas tendências. O mais raro, todavia, é encontrar um diarista que de tempos em tempos não impugne ou renegue o exercício que se impôs, enquanto o prossegue, porque deixou de confiar em suas virtudes, ou porque se viu em flagrante delito de exibicionismo e afetação. O caso de Barthes é, se quisermos, anômalo, já que questiona o exercício mas a partir de fora, procurando justificativas para saber se finalmente lhe conviria assumi-lo. Como afirma Genette, depois de dar várias voltas ao que julga ser uma anomalia sintática na primeira frase de "Deliberação"19, "ce qui définit le diariste, c'est moins la constance de sa pratique que celle de son projet"

Por falta de convicção ou excesso de prevenções, Barthes nunca assumiu o diário como projeto existencial; com intermitências simulou manter um, contudo nada mais era que um experimento literário. ${ }^{21} \mathrm{O}$ descrédito no qual as funções espirituais da escrita de diário haviam caído, segundo seu juízo, denunciava a inutilidade de sua prática. A única justificativa possível para sustentá-la seria então de ordem estética: trabalhar as anotações segundo a poética dos incidentes (a da suspensão da ênfase e da arrogância) para que o simulacro de diário se converta em obra. Esta exigência moral encobre uma distorção a que respondem as debilidades éticas do experimento barthesiano. $\mathrm{O}$ devir-obra do diário é um dom da leitura, jamais o resultado de uma deci-
18. Idem. La preparación de la novela. Notas de cursos y seminarios en el Collège de France, 2005, p. 230.

19. “Je n'ai jamais tenu de journal - ou plutôt je n'ai jamais su si je devais en tenir un" ("Nunca mantive um diário - ou melhor, nunca soube se deveria ter um"). Idem. Lo obvio y lo obtuso Imágenes, gestos, voces, 1886 , p. 365.

20. "[O] que define o diarista é menos a constância de sua prática que aquela de seu projeto" (N. do T.). GENETTE, Gérard. "Le Journal, l'antijournal". Poétique, 1981, p. 317.

21. A propósito de "Noites de Paris", escreve Edmundo Bouças: "Ao simular um diário, mas fazendo de cada fragmento um 'simulacro de romance', a demanda do romanesco sugere ao diarista-narrador que se observe observando as próprias oscilações sobre a conduta do Desejo". BOUÇAS, Edmundo. "Qui je dois désirer (Deliberação de um ecrivain-dandy)", 2005, p. 94. 
22. Para uma aproximação ao conceito de "ato diarístico", ver, mais adiante, "Em trânsito a lugar algum. Sobre o Diário de uma passageira de Ágata Gligo". (Trata-se do último ensaio do livro de Alberto Giordano, em que, numa nota, ele deixa claro que concebe o "ato diarístico" como uma extensão do conceito de "ato autobiográfico"; N. T.). Cf. GIORDANO, Alberto. La contraseña de los solitarios. Diarios de escritores, 2011, p. 136, nota 2.

23. BARTHES, Roland. Lo obvio y lo obtuso Imágenes, gestos, voces, 1986 , p. 365.

24. Idem. Variaciones sobre literatura, 2003, p. 159.

25. PIZARNIK, Alejandra. Diarios, 2003, p. 234.

26. Ibidem, p. 345.

27. Ibidem, p. 482.

28. Ibidem, p. 504. são de autor. É o leitor, quando inventa o diarista como personagem a partir dos desdobramentos que se desprendem do ato $^{22}$ da anotação, que opera um deslocamento para além do egotismo: a afirmação da vida como potência impessoal. É somente da perspectiva de um autor demasiado interessado na imagem que dele poderiam fazer seus leitores (Barthes delibera a partir desta inquietude) que o diário é "discurso" mas não "texto" 23 (Barthes, 1986: 376), um jogo de linguagem codificado e não uma experiência dos descentramentos enunciativos. Quando a generosa disposição do leitor intervém até nos blocos de narcisismo mais compactos podem ser descobertas gretas pelas quais passam sopros de vida desconhecidos.

Uma das falsas certezas com que Barthes sustentou sua "Deliberação" de 1979 já estava enunciada, treze anos antes, na resenha de Le Journal intime, de Alain Girard: "o intimismo do diário é hoje em dia impossível" 24 , porque os escritores modernos renegam o estatuto psicológico do en e resistem a falar de si mesmos na primeira pessoa. A menção aos nomes de John Cheever, Alejandra Pizarnik, Rosa Chacel e Julio Ramón Ribeyro, quatro diaristas extraordinários, ativos em 1966, desbarata com um só golpe o caráter evidente e reivindicável da suposta caducidade do gênero. Os quatro correram os riscos da auto-complacência e da impostura, às vezes com prazer, às vezes com espanto, pois acreditavam na necessidade do exercício autobiográfico, embora lhes sobrassem razões para se enfurecer com relação a suas virtudes espirituais, e para temer sua continuidade. 1962: "O eu de meu diário não é, necessariamente, a pessoa ávida por escrever sua sinceridade"25; 1963: "Escrever um diário é dissecar-se como se estivesse morta"26; 1969: "Acalentei o sonho de viver sem tomar notas, sem escrever um diário. A finalidade consistia em transmutar meus conflitos em obras, não em anotá-los diretamente. Porém me asfixio e ao mesmo tempo me mareia o espaço infinito de viver sem o limite do "diário""27. 1971: "Eis-me aqui escrevendo meu diário, por mais que saiba que não deve ser assim, que não devo escrever meu diário" (Idem: 504) ${ }^{28}$. Pizarnik delibera enquanto atua; a deliberação é afetada porque também aposta no valor de obra de seu diário. Terá sucesso, como sempre ocorre, postumamente (todos os diários são lidos como obra da perspectiva da morte do autor), quando ficou claro que a forma e o ritmo do diário eram aquilo que essa vida necessitava para manifestar-se como processo de demolição em contínuo recomeço.

A crença do diarista nas potências espirituais de sua prática (potências sempre ambíguas, que têm a ver com a conservação e o dispêndio, com a esterilidade e a criação, com o resguardar-se e o se expor) é uma conjectura do leitor, feita para explicar para si mesmo a persistência do exercício aquém de qualquer álibi razoável, e a ocorrência daquilo que Barthes denomina, em sua 
aproximação ao Romance como terceiro gênero, "Momentos de Verdade" ${ }^{29}$, momentos nos quais uma notação transmite a verdade de um afeto como algo irrepresentável porém evidente, graças à força das emoções que desperta. Compreende-se que, em nome da "psicanálise, da crítica sartriana à má consciência [e] da crítica marxista das ideologias" 30 (é preciso ver com quantos tijolos de diferentes consistências e formatos está feito este muro supostamente intransponível), Barthes declara obsoletos os impulsos confessionais e a busca de sinceridade, porque pensa no diário que não queria escrever. Mas quando o leitor encontra, naquele que manteve durante 1977, na entrada de 13 de agosto, esta frase que irrompe depois do relato de um acidente banal: "De repente me é totalmente indiferente não ser moderno" (Barthes, 1986: 374) ${ }^{31}$, tem a impressão de estar na presença de um ato de purificação, nascido da necessidade de se desligar daquilo que até então era um valor profissional, para se abrir às incertezas da vida que recomeça sob o alento do anacrônico. $\mathrm{O}$ ato, não importa que não possamos avaliá-lo em termos de sinceridade, impõe-se como autêntico porque tem a força transformadora da confissão: o escritor-diarista trabalha sobre si mesmo, observa-se ativamente a fim de fabricar para si uma verdade que convenha aos desejos de sua idade.

Em outro diário que começou a manter imediatamente depois de por o ponto final em "Deliberação", aquele que os editores intitularam "Noites de Paris", Barthes aprofunda sua vontade de anacronismo. Não apenas se desprende da moral vanguardista como também questiona o valor daqueles que a representam (Sollers? Sarduy?): "Sempre esta mesma ideia [ao passar dos textos supostamente transgressores ao "livro verdadeiro", Memórias de ultratumba]: e se os Modernos tiverem se equivocado? E se não existisse talento?" 32 . Talvez só um crítico que também se entusiasme, em tempos de culturalismo e "pós-autonomia", com o futuro da literatura como mistério inatual pode sentir que a confissão deste desengano configura um "momento de verdade". Há outros registros, como as interferências do luto pela morte da mãe através de um ato falho, ou a contração infantil do corpo adulto quando vê chegar uma reprimenda, que poderiam comover quase qualquer leitor pela sobriedade com que envolvem uma carga de afetos íntimos, associados ao original e originário das experiências intersubjetivas.

Como não chegou a publicá-lo em vida e ainda lhe faltavam alguns retoques finais, ignoramos se "Noites de Paris" pôde significar para Barthes uma tentativa lograda de converter o diário em Romance. O leitor fica insatisfeito porque a retórica conclusiva em demasia, com que se encerra a última entrada, torna evidente a simulação. Depois de anotar ao longo de dezesseis jornadas a repetição desgastante de recusas, fastídios e desilusões, a mescla de tédio e desespero que preside às vadiagens
29. BARTHES, Roland. La preparación de la novela. Notas de cursos y seminarios en el Collège de France, 2005, p. 159.

30. Idem. Lo obvio y lo obtuso

Imágenes, gestos, voces, 1986, p. 366.

31. Ibidem, p. 374.

32. Idem. Incidentes, 1987b, p. 94. 
33. Ibidem, p. 130.

34. Alusão ao "Café de Flore", no Boulevard Saint-Germain, em Paris (N. T.). noturnas, Barthes abusa da lógica discursiva, e coloca ponto final (no espessamento da vida e no registro de seus pormenores).

Toquei um pouco de piano para O., a seu pedido, sabendo que acabara de renunciar a ele para sempre; tem olhos bonitos e uma expressão doce, suavizada pelos cabelos longos: eis aqui um ser delicado mas inacessível e enigmático, terno e distante ao mesmo tempo. Depois lhe disse para ir embora, com a desculpa do trabalho, e a convicção de que havíamos terminado, e de que, com ele, algo mais havia terminado : o amor de um rapaz (Barthes, 1987b: 130) ${ }^{33}$.

Se nos "momentos de verdade" o leitor sente a passagem imperceptível da vida através da escrita, este seria um "momento de impostura", pois reconhecemos que a autofiguração em chave de serena assunção das limitações existenciais está a serviço de um programa de renovação que, sendo demasiado declarado, converteu-se em moral. Já que o interesse prioritário de Barthes era retórico, para garantir o efeito de autenticidade devia ter acrescentado pelo menos outra entrada, com o registro de uma noite mais no Flore $e^{34}$, expectante e no limite da penúltima desilusão. Os verdadeiros diários se interrompem, não se encerram, porque a vida não conhece pontos finais.

Nas origens literárias do gênero, Amiel ressaltou a incompatibilidade entre o diário íntimo e a vida matrimonial. Quando não é celibatário, o diarista leva uma vida dupla, como Cheever ou Gide. Barthes, que em sua resenha do livro de Girard relembra a rivalidade entre os cadernos secretos e a figura da esposa, é, desta perspectiva, um intimista clássico: somente depois que a morte dissolveu o vínculo amoroso que havia contraído com a mãe para toda a vida, manteve um verdadeiro diário. Mais que o desaparecimento de um ser maravilhoso, idealizado pela devoção (recorda-a generosa, nobre e infinitamente boa, imaculada de neurose), o que abriu em seu coração uma ferida irreversível e o impulsionou a escrever foi o desaparecimento daquilo que eram enquanto viviam juntos (sempre o fizeram), o idílio que os mantinha inseparáveis. O Diário do luto registra, preserva de infecções sentimentais e tenta converter em princípio ativo as aflições de um processo de viuvez, mais que de orfandade. Como revela um universo privado submetido às tensões ocultas do íntimo, e Barthes o manteve sem propósitos de convertê-lo em obra, é possível discutir, como o fez François Wahl (2009), a legitimidade de sua edição póstuma. O leitor que veio seguindo, atentamente, os experimentos de Barthes com a articulação entre escrita fragmentária e impulso afetivo recebe-o como um obséquio curioso e inesperado.

"15 de março de 1979. Só eu conheço meu caminho faz um ano e meio: a economia do luto imóvel e não espetacular..." 
(Barthes, 2009: 244) ${ }^{35}$. A escrita secreta, clandestina, que registra os movimentos de uma aflição subtraída às trivialidades do mundano, é aquela que corresponde a um exercicio espiritual no qual está em jogo algo mais exigente que a figuração de uma imagem de escritor, a construção de si mesmo como sujeito moral. À margem de qualquer deliberação, a forma do diário se impôs a Barthes como a mais conveniente para um registro das flutuações anímicas que pudesse servir como técnica de cuidado e potenciação do intransferível (esse é o valor superior). Depurar o luto em sua rareza, examinar em detalhe, até estranhar a si mesmo, as alternâncias e as simultaneidades de emotividade e reserva, de ligeireza e desconsolo, permite-lhe viver a aflição ativamente, não para fazer literatura (a ideia o atemoriza), mas para submeter a dor à prova do literário. "30 de novembro. Não dizer Luto. É demasiado psicanalítico. Não estou de luto. Estou aflito” (Idem, 84) ${ }^{36}$. Para alcançar a extenuação do sentido, a vivência da separação como flagelo íntimo, irrepresentável, deve-se começar resistindo à desfiguração provocada pelos lugares comuns. Esta dor é única, irrepetível, e tomo a palavra para dizer que não há palavra capaz de nomeá-la. A utopia de uma dor sem emotividade, pura aflição incomunicável, é, como todas as utopias literárias, obra do excesso amoroso e do orgulho.

\section{Referências}

BARTHES, Roland. Roland Barthes por Roland Barthes. Trad. de Julieta Sucre. Barcelona: Kairós, 1978. [Em português: Roland Barthes por Roland Barthes. Trad. de Leyla Perrone-Moisés. São Paulo: Estação Liberdade, 2003].

- El placer del texto seguido por Lección inangural. Trad. de Nicolás Rosa y Oscar Téran. $4^{a}$ ed. México: Siglo XXI, 1982. [Em português: O prazer do texto. Trad. de Jacó Guinsburg. São Paulo: Perspectiva, 2008. Aula (Aula inaugural da Cadeira de Semiologia Literária do Colégio de França). Trad. de Leyla Perrone-Moisés. São Paulo: Cultrix, 1987].

Lo obvio y lo obtuso Imágenes, gestos, voces. Trad. de C.

Fernández Medrano. Barcelona: Paidós, 1986. [Em português: O óbvio e o obtuso (ensaios críticos III). Trad. de Léa Novaes. Rio de Janeiro: Nova Fronteira, 1990].

El susurro del lenguaje. Más allá de la palabra y la escritura.

Trad. de C. Fernández Medrano. Barcelona: Paidós, 1987a.

[Em português: O rumor da língua. Trad. de Mário Laranjeira.

São Paulo: Brasiliense, 1988].
35. BARTHES, Roland. Diario del duelo, 25 de octubre de 1977 15 de septiembre de 1979, 2009, p. 244.

36. Ibidem, p. 84. 
. Incidentes. Ed. de François Wahl. Trad. de Jordi Llovet. Barcelona: Anagrama, 1987b. [Em português: Incidentes. Trad. de Mário Laranjeira. São Paulo: Martins Fontes, 2004].

. Variaciones sobre literatura. Sel. y trad. de Enrique Folch Gonzáles. Buenos Aires: Paidós, 2003. [Em português: O prazer do texto precedido de Variações sobre a escrita. Trad. de Luis Felipe Sarmiento. Lisboa: Edições 70, 2009].

- La preparación de la novela. Notas de cursos y seminarios en el Collège de France. 1978-1979 e 1979-1980. Texto establecido, anotado y presentado por Nathalie Léger. Trad. de Patricia Wilson. Edición en español al cuidado de Beatriz Sarlo. Buenos Aires: Siglo XXI, 2005. [Em português: A preparação do romance (vol. I - Da vida à obra). Trad. de Leyla PerroneMoisés. São Paulo: Martins Fontes, 2005. A preparação do romance (vol II - A obra como vontade). Trad. de Leyla Perrone-Moisés. São Paulo: Martins Fontes, 2005].

. Diario del duelo, 25 de octubre de 1977 - 15 de septiembre de 1979. Trad. de Adolfo Castañon. México: Siglo XXI, 2009. [Em português: Diário de Luto. Trad. de Leyla Perrone-Moisés. São Paulo: Martins Fontes, 2011].

- Diario de mi viaje a China. Edición a cargo de Anne Herscberg Pierrot. Trad. de Núria Petit Fonserè. Barcelona: Paidós, 2010. [Em português: Cadernos da viagem à China. Trad. de Leyla Perrone-Moisés. São Paulo: Martins Fontes, 2012].

BOUÇAS, Edmundo. "Qui je dois désirer (Deliberação de um écrivain-dandy)". In: CASA NOVA, Vera; GLENADEL, Paula (Orgs.). Viver com Barthes. Rio de Janeiro: 7Letras, 2005, p. $91-104$.

DU BOS, Charles. Extractos de un Diario. 1908-1928. Trad. de León Ostrov. Prólogo de Eduardo Mallea. Buenos Aires: Emecé, 1947.

GENETTE, Gérard. "Le Journal, l'antijournal”. Poétique 47, p. 315-322, 1981.

GIORDANO, Alberto. Roland Barthes. Literatura y poder. Rosario: Beatriz Viterbo, 1995.

PIZARNIK, Alejandra. Diarios. Edición a cargo de Ana Becciu. Barcelona: Lumen, 2003. 